\title{
Contribution to the knowledge of some rare plant communities from the southwestern Iberian System
}

\author{
M. Pilar Rodríguez-Rojo, Guillermo Crespo, Jaime Madrigal \\ \& Federico Fernández-González (*)
}

\begin{abstract}
Rodríguez-Rojo, M.P., Crespo, G., Madrigal, J. \& Fernández-González, F. Contribution to the knowledge of some rare plant communities from the southwestern Iberian System. Lazaroa 33: 27-42 (2012).

Several herbaceous communities from the southwestern Iberian System poorly known from the phytosociological perspective are documented and framed into their correspondent syntaxa, including calcareous (Epipactido palustris-Primuletum farinosae) and siliceous sedge fens (Caricetum echinato-nigrae), Nardus swards (Genisto anglicae-Nardetum strictae), and rush meadows (Deschampsio hispanicae-Juncetum effusi and Hyperico undulati-Juncetum acutiflori). We also validate an unpublished association for thyme scrub communities of the endemic Thymus leptophyllus subsp. izcoi, proper from siliceous substrates in the north and southwestern Iberian System.
\end{abstract}

Keywords: Dry grasslands, Fens, Nardus stricta swards, Phytosociology, Rush meadows.

Resumen: Rodríguez-Rojo, M.P., Crespo, G., Madrigal, J. \& Fernández-González, F. Contribución al conocimiento de algunas comunidades vegetales raras del Sistema Ibérico suroccidental. Lazaroa 33: 27-42 (2012).

Se documentan desde el punto de vista fitosociológico algunas comunidades poco conocidas en el Sistema Ibérico suroccidental, entre las que se incluyen las turberas de cárices calcáreas (Epipactido palustris-Primuletum farinosae) y silíceas (Caricetum echinato-nigrae), los cervunales (Genisto anglicae-Nardetum strictae) y los prados-juncales (Deschampsio hispanicae-Juncetum effusi e Hyperico undulati-Juncetum acutiflori). Además, se valida y tipifica una nueva asociación para los tomillares de Thymus leptophyllus subsp. izcoi propios de afloramientos silíceos en el Sistema Ibérico septentrional y suroccidental.

Palabras clave: Cervunales, Fitosociología, Pastizales xerófilos, Prados juncales, Turberas.

\section{INTRODUCTION}

The vegetation of the southwestern ranges of the Iberian System has been less intensively prospected than in other neighbouring mountain ranges, excepting for some authors that in the 70s and 80 s, approached phytosociological monographs on the Serranía de Cuenca (LóPEZ-GonZÁLEZ, 1976, 1978) and Sierra de Albarracín (BARRERA, 1985). They pointed out important levels of community diversity and originality in this territory, as a consequence of a varied lithology, including calcareous and siliceous substrates (limestone, dolomites, slates, quartzites, red sandstones, albian sands, etc), combined with the complexity of relief. However, some types of vegetation have not been enough sampled and consequently their syntaxonomical position is far from being rightly framed. This fact is more evident in the case of several siliceous fens and grasslands.

The typical geomorphology in the southwestern Iberian System is a complex of Late Cretaceous calcareous highlands (Muelas) and Alpine rangelands (Sierras), among which the rivers have excavated deep gorges. Although calcareous bedrocks are dominant, siliceous bedrocks have important representations, as red sandstones (rodenos), typical from the Late Triasic Period, in the low belts of siliceous mountains, and Paleozoic quartzites in the high belts, such in the case

\footnotetext{
* Departamento de Ciencias Ambientales. Instituto de Ciencias Ambientales. Universidad de Castilla-La Mancha. Avda. Carlos
} III s/n. E-45071 Toledo. E-mail: MPilar.Rodriguez@uclm.es 
of Sierra de Albarracín, Sierra Menara (Teruel), and Sierra Valdemeca (Cuenca). Moreover, strips of sandy lands from the Albian Period (Early Cretaceous) crop out at the foothills of the calcareous highlands. In this geomorphological and lithological framework, a high diversity of grasslands occurs. Cryoturbated calcareous short grasslands colonize the ridges and slopes of mountains and highlands, while the wet and mesic grasslands fill the valley bottoms and basins. Many of these types of vegetation are included in the Catalogue of Habitats of Special Protection in Castilla-La Mancha (Nature Conservation Law 9/1999) or in the Annex I of Habitats Directive (92/43/EEC): calcareous fens, sphagnum acid bogs, semi-natural dry grasslands, Nardus swards, Molinia and rush meadows, alpine and subalpine calcareous grasslands, etc). Moreover, other habitats not taken into account in these catalogues but hosting rare local species accomplish the whole floristic and community diversity in the territory, such as the siliceous grasslands.

To fill up the gaps in knowledge just exposed, we present the results of a phytosociological study on some herbaceous communities poorly known in the southwestern Iberian System, as it is the case of calcareous and acid fens, Nardus swards, rush meadows and siliceous thyme-grasslands.

\section{MATERIALS AND METHODS}

\section{STUDY AREA}

The study area comprises a whole of rangelands in Guadalajara, Cuenca and Teruel provinces that according to the geomorphological sectorization of GUTIÉRREZ \& PEÑA (1994) belongs to the central sector and south-western area of the Iberian System (Cordillera Ibérica). The main rangelands prospected were Sierra de Albarracín, Sierra de Valdemeca and Serranía de Cuenca. Sierra de Pela was excluded from the study area. According to the bioclimatic typology of RIVAS-MARTíNEZ \& al. (2007), the territory is in the transition of macrobioclimates Mediterranean, in the lowlands, and Temperate (submedi- terranean variant) in the uplands. The uplands are ascribed to two bioclimatic belts: upper suprasubmediterranean and lower orosubmediterranean, with ombrotypes from upper subhumid to upper humid. Biogeographically, the territory is framed into the Maestracensean and Celtiberian-Alcarrean sectors, Mediterranean Central Iberian Province (RIVAS-MARTÍNEZ, 2011).

Field sampling was carried out during 2009 to 2012 following the methodology and protocols commonly used in phytosociology. Plot size was fixed as a rule in $100 \mathrm{~m}^{2}$, excepting when community representations were clearly restricted to areas of a lesser extent.

\section{RESULTS AND CONCLUSIONS}

\section{Calcareous fens}

Epipactido palustris-Primuletum farinosae Rivas Goday \& Borja 1961 (Table 1)

Lectotypus (hoc loco design.): Rivas Goday \& Borja (1961), Anales Inst. Bot. Cavanilles 19: 174-175, table 37, rel. 3.

(Caricion davallianae Klika 1934, Caricetalia davallianae Br.-Bl. 1949, Scheuchzerio palustrisCaricetea nigrae Tüxen 1937 nom. mut.propos.)

The alkaline fens and wetlands of Caricion $\mathrm{da}$ vallianae are dominated by small sedges and brown mosses on soils permanently waterlogged with a calcareous water supply. In the Iberian Peninsula, they are more frequent in the Eurosiberian Region but also occur in some Mediterranean mountains where the climatological conditions (cold temperatures) favor the formation of peat. The Iberian System marks the southern limits of these communities in the Iberian Peninsula. These fens are really rare in the territory and only appear in some bottom valleys, water springs, or overflooded stream borders, on flat or gentle sloped terrains.

Floristically, Maestracensean alkaline fens are characterized by Eriophorum latifolium, Carex davalliana, Carex lepidocarpa, Carex nigra, Carex mairei, Pinguicula vulgaris and Triglochin palustris as the most frequent species, but they also host 
Table 1

Epipactido palustris-Primuletum farinosae Rivas Goday \& Borja 1961

(Caricion davallianae, Caricetalia davallianae, Scheuchzerio palustris-Caricetea nigrae)

\begin{tabular}{|c|c|c|c|c|c|c|c|c|c|c|c|}
\hline Altitude (m) & 1574 & 1523 & 1519 & 1616 & 1414 & 1600 & 1618 & 1472 & 1567 & 1581 & \\
\hline Area $\left(m^{2}\right)$ & 4 & 50 & 100 & 100 & 100 & 100 & 100 & 50 & 50 & 50 & \\
\hline Exposure & - & $\mathrm{O}$ & - & $\mathrm{E}$ & $\mathrm{E}$ & $\mathrm{O}$ & NE & NE & - & S & \\
\hline Slope $\left({ }^{\circ}\right)$ & - & 15 & - & 15 & 30 & 5 & 2 & 15 & - & 5 & \\
\hline Cover $(\%)$ & 90 & 100 & 100 & 90 & 100 & 100 & 90 & 100 & 80 & 100 & \\
\hline Cover of bryophytes (\%) & 10 & - & - & 10 & - & - & 10 & - & 20 & - & \\
\hline Releve N. & 1 & 2 & 3 & 4 & 5 & 6 & 7 & 8 & 9 & 10 & Syn \\
\hline $\begin{array}{l}\text { Characteristics of alliance } \\
\text { and order: }\end{array}$ & & & & & & & & & & & $\begin{array}{l}\text { Freq. } \\
(\%)\end{array}$ \\
\hline Carex davalliana & 2 & 3 & 2 & . & 3 & 2 & 5 & 4 & 1 & 3 & 90 \\
\hline Carex lepidocarpa & 2 & 2 & 2 & 2 & 2 & 2 & . & 1 & 2 & 1 & 90 \\
\hline Eriophorum latifolium & 3 & 2 & 3 & 2 & 4 & 3 & 3 & . & . & . & 70 \\
\hline Juncus pyrenaeus & . & 1 & . & . & 1 & . & . & 1 & . & 1 & 40 \\
\hline Primula farinosa & . & . & 1 & 1 & . & . & . & . & . & . & 20 \\
\hline Epipactis palustris & . & . & . & . & . & . & + & . & . & . & 10 \\
\hline Spiranthes aestivalis & . & . & . & . & & . & . & + & . & . & 10 \\
\hline Territorial differentials: & & & & & & & & & & & \\
\hline $\begin{array}{l}\text { Carex mairei } \\
\text { Characteristics of class: }\end{array}$ & . & 2 & 2 & . & 2 & 2 & . & 2 & . & 1 & 60 \\
\hline Carex nigra & 2 & 2 & 2 & 2 & 1 & . & . & 2 & 3 & 3 & 80 \\
\hline Pinguicula vulgaris & 1 & 1 & 1 & 1 & 2 & . & . & 1 & 1 & 1 & 80 \\
\hline Triglochin palustris & 1 & 1 & 1 & 2 & . & + & . & . & 2 & 1 & 70 \\
\hline Parnassia palustris & . & 1 & . & . & . & . & . & . & 1 & + & 30 \\
\hline Eleocharis quinqueflora & . & 1 & 2 & . & . & . & . & . & . & . & 20 \\
\hline $\begin{array}{l}\text { Carex echinata } \\
\text { Companions: }\end{array}$ & . & . & . & . & . & . & . & 2 & . & . & 10 \\
\hline Potentilla erecta & 1 & 1 & 1 & 1 & 1 & 1 & 1 & 1 & 1 & 1 & 100 \\
\hline Lotus corniculatus & + & 1 & + & . & 1 & 1 & + & . & + & + & 80 \\
\hline Carum verticillatum & . & 1 & . & . & 1 & 1 & 1 & 1 & 1 & 1 & 70 \\
\hline Juncus articulatus & 1 & . & . & 1 & 1 & . & 1 & 1 & 1 & 1 & 70 \\
\hline Molinia caerulea & . & 2 & 1 & 2 & 1 & . & 1 & 2 & . & 2 & 70 \\
\hline Carex panicea & 1 & 1 & + & . & 1 & . & 1 & 1 & . & . & 60 \\
\hline Briza media & . & 1 & . & 3 & 1 & 1 & . & + & . & 1 & 60 \\
\hline Carex disticha & 1 & . & . & . & 1 & 1 & . & . & + & 1 & 50 \\
\hline Succisa pratensis & . & 1 & 1 & . & 2 & 1 & . & 2 & . & . & 50 \\
\hline Carex flacca & . & . & . & . & 1 & 1 & 1 & 1 & . & . & 40 \\
\hline Linum catharticum & . & . & . & . & + & 1 & 1 & . & . & + & 40 \\
\hline Plantago media & . & . & + & . & . & 1 & . & . & + & 2 & 40 \\
\hline Trifolium pratense & . & . & . & . & + & . & . & + & + & 1 & 40 \\
\hline Cirsium arvense & . & 1 & + & . & + & . & . & . & . & . & 30 \\
\hline Equisetum palustre & . & 1 & + & . & . & . & 3 & . & . & . & 30 \\
\hline Euphrasia hirtella & + & . & . & . & . & . & . & . & 1 & + & 30 \\
\hline Festuca trichophylla s.l. & . & 1 & 1 & . & . & . & . & . & 1 & . & 30 \\
\hline Rhinanthus minor & + & . & . & . & . & . & . & . & + & + & 30 \\
\hline Mentha longifolia & . & + & . & . & . & . & . & + & . & + & 30 \\
\hline Prunella vulgaris & . & . & . & . & . & . & . & + & 2 & 1 & 30 \\
\hline Schoenus nigricans & . & . & . & . & 1 & 1 & . & 1 & . & . & 30 \\
\hline
\end{tabular}

Other species: Dactylorhiza maculata 2 in 5 and + in 8; Agrostis stolonifera and Juncus subnodulosus 1 in 2; Juncus acutiflorus and Phragmites australis 1 and Phleum bertolonii + in 3; Scirpoides holoschoenus 1 in 4; Taraxacum vulgare + in 5; Galium verum and Polygala vulgaris 1, Dactylorhiza elata, Juncus conglomeratus, Leontodon carpetanus and Tetragonolobus maritimus + in 6; Danthonia decumbens + in 8; Trifolium repens and Cardamine castellana 1 in 9; Leontodon hispidus 1 in 10. 
Localities: 1: Cuenca, Serranía de Cuenca, Cañada de los Periquetes, 30TXK0271, 15-7-2009; 2-3: Cuenca, Sierra de Zafrilla, Prado Redondo, 30TXK1355, 27-7-2009; 4: Cuenca, Sierra de Zafrilla, Rincón de Palacios, 30TXK1058, 27-7-2009; 5,8: Cuenca, Serranía de Cuenca, río Chico, 30TWK8687, 28-7-2009; 6: Guadalajara, Sierra de Albarracín, Fuente del Pajarero, 30TXK1083, 30-6-2010; 7: Cuenca, Serranía de Cuenca, Arroyo del Chispo, 30TXK0170, 8-7-2009; 9: Cuenca, Serranía de Cuenca, Collado Manchego, 30TWK9481, 15-7-2009; 10: Cuenca, Serranía de Cuenca, Umbría de San Felipe, manantiales del Júcar, 30TWK9872, 15-7-2009.

some rare species such as Dactylorhiza incarnata, Epipactis palustris, Gentianella amarella, Juncus pyrenaeus, Spiranthes aestivalis, Primula farinosa, Swertia perennis, Potentilla fruticosa and Menyanthes trifoliata (MATEO \& al., 1995; MATEO \& al., 2001; GÓMEZ-SERRANO \& MAYORAL, 2003; GÓMEZ-SERRANO \& LAGUNA, 2011; etc.). In comparison with Orocantabrian and Pyrenean fens, the floristic composition is poor in character species of the alliance and order, lacking among them some plant specialist of these temperate fens: Equisetum variegatum, Pinguicula grandiflora, Pedicularis mixta, Selaginella selaginoides and Tofieldia calyculata (JIMÉNEZ-ALFARO \& al., 2012).

The oldest name available for these communities seems to be the proposed by RIVAS GODAY \& BORJA (1961: 173-175) with 3 relevés from the uplands of Sierra de Gúdar. Despite the name is not very fortunate, because the naming species are neither common nor differential in the association, the relevés contain the main species proper of the regional mires (Eriophorum latifolium, Carex davalliana, Carex lepidocarpa, Triglochin palustris, Juncus pyrenaeus, Parnassia palustris, etc). Although Eleocharis quinqueflora and Carex maire $i$ are absent from these relevés, they are present in other relevés of mires from the same area (RIVAS GODAY \& BORJA 1961: 172, 176). The name has not been taken into account in later revisions probably because its confuse formulation: "Asociación regional [regional association]: Epipactideto-Primuletum farinosae/ Caricetum davallianae regional, molinietosum", but from the text of the description it is quite clear the authors' intention of proposing a new regional association within the group of associations dominated by Carex $\mathrm{da}$ valliana, and that the "name' "Caricetum davallianae regional, molinietosum" is merely explanatory and must be intended as a 'syntaxon without rank', according to the note to Art. $3 \mathrm{c}$ added in the last edition of the ICPN (WEBER \& al., 2000). The same authors proposed two other names for fen communities in his monograph: the "community of Eriophoretum latifolii s.l. molinietosum" (RIVAS GODAY \& BORJA, 1961: 175-177) that must be considered invalid according to Art. $3 \mathrm{~d}$ of the ICPN; and the association Carex loscosii [C. mairei] et Juncus arcticus pyrenaeus (RIVAs GODAY \& BORJA, 1961: 171-173), a valid name ascribed to Caricion canescenti-fuscae (i.e., Caricion nigrae) whose diagnostic relevés come from the same localities than the ones of Epipactido-Primuletum farinosae and are also dominated by character species of Caricetalia davallianae. Hence we consider that both names fit into the local range of variation of the same association and must be considered as syntaxonomic synonyms of Epipactido-Primuletum farinosae.

More recently PITARCH (2002: 261) proposed a Maestracensean association for Eriophorum latifolium fens in the southeastern Iberian System, under the name Epipactido palustris-Eriophoretum latifolii and framed into Molinion caeruleae (Molinio-Arrhenatheretea). Later on, other authors (Del EgIDo \& Puente, 2011) corrected the syntaxonomical position of this association into Caricion davallianae (Scheuchzerio palustrisCaricetea nigrae). This association includes explicitly the "community of Eriophoretum latifolii s.l. molinietosum" proposed by RIVAS GoDAY \& BORJA (op. cit.) with relevés bearing Carex davalliana and C. lepidocarpa, unlike the two relevés (including the holotype of the association) on which the name of Pitarch was based. Dynamic transitions and mosaics among true fen communities and Molinia dominated meadows (Deschampsio-Molinietum caeruleae (RIVAS GODAY \& BORJA 1961) RIVAS-MARTíneZ 2002) are relatively frequent in these wetlands and this is probably the interpretation for the relevés of Pitarch. Our Table 1 shows the typical Maestracensean alkaline fens with a higher proportion of species of 
Scheuchzerio palustris-Caricetea nigrae, for which we consider that the name Epipactido palustris-Primuletum farinosae can be reasonably applied.

A further phytosociological name for these fens was proposed by NAVARRO (1986) with relevés from Sierra de Cabrejas (northern Iberian System): Carici mairei-Eriophoretum latifolii G. Navarro ined. (nom. inval., art. 1). The relevés of Navarro are also characterized by Eriophorum latifolium, Epipactis palustris and Carex mairei, although contain a high abundance of Molinietalia species, being also transitional to Molinion meadows. In spite of this fact, LOIDI \& al. (1997: 520) compiled and described this association name in correct floristic and ecological terms, attributing it a distribution Maestracensean and Celtiberian-Alcarrean, but did not validate the name.

\section{ACID BOGS}

\section{Caricetum echinato-nigrae Rivas-Martínez 2002 (Table 2)}

(Caricion nigrae Koch 1926 nom. mut. propos., Caricetalia nigrae Koch 1926 nom. mut. propos., Scheuzchzerio palustris-Caricetea nigrae Tüxen 1937 nom. mut. propos.)

Oligotrophic fens of small sedges and bryophytes, especially of the genus Sphagnum, typical of supra and orotemperate belts under continental and suboceanic climates. The acid bogs from siliceous mountains of the southwestern Iberian System (Sierra del Tremedal and siliceous outcrops in Alto Tajo), locally named as "gotiales" or "goteales", are floristically similar to the acid fens described from the Central System (RIVAS-MARTÍNEZ, 1964; FERNÁNDEZ-GONZÁLEZ, 1988; SÁNCHEZ-MATA, 1989; DE la CRUZ, 1994; SARDINERO, 2005) and recognized also in the northern Iberian System (NAVARRO 1986, 1987), and may be grouped in the same association: Caricetum echinatonigrae. Maestracensean acid bogs are characterized by the small sedges Carex echinata, $C$. nigra and C. demissa, as it occurs in the Carpetan bogs, though Agrostis canina, Potentilla palustris and Viola palustris are absent (nevertheless the three species reach the northern Oroiberian mountains). On the other hand, Pyrenean acid bogs represent a very different association (Caricetum nigrae $\mathrm{Br}$.Bl. 1915 nom. mut. propos.) richer in oligotrophic bog species (Carex canescens, Juncus filiformis, Phleum alpinum) that are lacking in the Oroiberian and Carpetan-Leonese bogs. In any case, the presence of Eriophorum angustifolium and Carex rostrata introduces a moderate differentiation between the Oroiberian and the Carpetan-Leonese fens, thus a new subassociation may be proposed to designate Oroiberian acid bogs: Caricetum echinato-nigrae eriophoretosum angustifolii subass. nova hoc loco (holotypus subassociatio: Table 2, rel. 1).

The fens of the Sierra del Tremedal (included in the List of Ramsar Wetlands of International Importance) have a periglacial origin and a scattered distribution in concavities excavated by periglacial eroding processes (rocky channels, screes, ...). They are also present in slow-running streams, springs, and poor-drainage temporal ponds, where accumulation of undecomposed organic matter is favored. Peat-producing vegetation is composed of small sedges, Sphagnum mosses (S. palustre, S. capillifolium, S. teres,... Munín \& Fuertes, 2001), and some other bog and fen species, such as Drosera rotundifolia and Parnassia palustris. In sites with intense accumulation of peat, Sphagnum hummocks disconnected from the soil water table can develop and evolve to dryer conditions favorable for the settling of Calluna vulgaris and Polytrichum commune. Most of these peat bogs grow in moderate shadow environments, in the clearings of Pinus sylvestris forests, where pine trunks behave as support for Sphagnum mosses to raise up and acquire hummock growth forms. Further research is needed to ascertain if these incipient hummocks where the ombrotrophic Sphagnum capillifolium is abundant can be referred to border representations of Oxycocco-Sphagnetea.

The association name (Caricetum echinato-nigrae) requires also some nomenclatural explanations. Since Carex fusca var. carpetana C. Vicioso and the combinations derived from it (C. fusca subsp. carpetana C. Vicioso ex Rivas-Martínez, $C$. nigra subsp. carpetana C. Vicioso ex Rivas-Martí- 
Table 2

Caricetum echinato-nigrae Rivas-Martínez 2002 eriophoretosum angustifolii subass. nova (Caricion nigrae, Caricetalia nigrae, Scheuzchzerio palustris-Caricetea nigrae)

\begin{tabular}{|c|c|c|c|c|c|c|c|c|c|c|c|}
\hline Altitude (m) & 1557 & 1650 & 1480 & 1480 & 1550 & 1550 & 1506 & 1650 & 1685 & 1740 & \\
\hline Area $\left(m^{2}\right)$ & 100 & 50 & 50 & 50 & 100 & 50 & 50 & 50 & 10 & 100 & \\
\hline Exposure & $\mathrm{E}$ & - & - & - & - & - & - & - & - & - & \\
\hline Slope $\left(^{\circ}\right)$ & 5 & - & - & - & - & - & - & - & - & - & \\
\hline Releve N. & 1 & 2 & 3 & 4 & 5 & 6 & 7 & 8 & 9 & 10 & Syn \\
\hline Characteristics: & & & & & & & & & & \multicolumn{2}{|c|}{ Freq. $(\%)$} \\
\hline Carex echinata & 1 & 2 & 1 & 2 & 2 & 2 & 3 & 3 & 2 & 3 & 100 \\
\hline Carex nigra & 1 & 1 & 2 & 1 & + & 1 & 1 & 2 & + & 1 & 100 \\
\hline Sphagnum palustre & 4 & 3 & & & . & . & . & + & . & . & 30 \\
\hline Sphagnum teres & . & 1 & 4 & 4 & . & . & . & . & . & . & 30 \\
\hline Sphagnum sp. & . & . & . & . & 2 & 2 & 2 & . & . & . & 30 \\
\hline Sphagnum capillifolium & . & . & . & . & . & . & . & . & 4 & 3 & 20 \\
\hline Drosera rotundifolia & 1 & 1 & 1 & 1 & . & . & + & . & + & 1 & 70 \\
\hline Epilobium palustre & 1 & . & . & . & + & 1 & + & + & + & . & 60 \\
\hline Carex demissa & 1 & 1 & + & . & . & . & 1 & 1 & . & . & 50 \\
\hline Parnassia palustris & 1 & + & . & . & . & . & 1 & 1 & . & . & 40 \\
\hline Eriophorum angustifolium & 3 & 2 & 2 & 1 & . & . & . & . & . & . & 40 \\
\hline Carex davalliana & 1 & 2 & . & . & . & . & + & . & . & . & 30 \\
\hline Calluna vulgaris & 1 & . & . & . & . & . & . & . & 1 & 1 & 30 \\
\hline Carex disticha & . & . & . & . & . & 1 & . & 2 & . & . & 20 \\
\hline Carex rostrata & . & . & + & . & . & . & . & + & . & . & 20 \\
\hline Companions: & & & & & & & & & & & \\
\hline Juncus effusus & . & + & 1 & 1 & 2 & 1 & 1 & 1 & 2 & . & 80 \\
\hline Potentilla erecta & 1 & 1 & . & . & 1 & 1 & 1 & 1 & 1 & 1 & 80 \\
\hline Carum verticillatum & + & 1 & . & . & 1 & + & 2 & + & + & + & 80 \\
\hline Molinia caerulea & 1 & 1 & 1 & 2 & . & . & 2 & . & 1 & 1 & 70 \\
\hline Pinus sylvestris & 1 & 2 & + & . & + & 2 & . & . & 1 & 2 & 70 \\
\hline Luzula multiflora & + & + & . & . & 1 & 1 & 1 & + & 1 & . & 70 \\
\hline Holcus lanatus & . & + & + & . & 1 & 1 & . & 1 & + & + & 70 \\
\hline Juncus acutiflorus & + & . & 1 & . & 1 & + & . & 1 & . & 1 & 60 \\
\hline Anthoxanthum odoratum & . & . & . & + & 1 & + & 1 & 1 & . & + & 60 \\
\hline Galium palustre & 1 & + & . & . & 1 & 1 & + & 1 & . & . & 60 \\
\hline Genista anglica & + & 1 & . & . & . & 1 & 1 & . & . & 1 & 50 \\
\hline Briza media & . & + & . & . & 1 & + & + & + & . & . & 50 \\
\hline Prunella vulgaris & . & . & . & . & 1 & 1 & . & + & + & . & 40 \\
\hline Dactylorhiza elata & + & + & . & . & 1 & . & . & . & + & . & 40 \\
\hline Hypericum undulatum & . & . & . & . & 2 & 1 & . & 1 & . & . & 30 \\
\hline Ranunculus repens & . & . & . & . & 1 & 1 & . & 1 & . & . & 30 \\
\hline Lathyrus pratensis & . & . & . & . & 1 & + & . & + & . & . & 30 \\
\hline Agrostis stolonifera & 1 & . & . & . & . & 1 & . & . & 1 & . & 30 \\
\hline Lychnis flos-cuculi & . & . & . & . & 1 & 1 & . & + & . & . & 30 \\
\hline Veronica scutellata & . & . & . & . & 1 & + & + & . & . & . & 30 \\
\hline Myosotis caespitosa & . & . & . & . & + & + & . & + & . & . & 30 \\
\hline
\end{tabular}

Other species: Carex panicea 1 in 2, + in 8; Lotus corniculatus + in 2 and 8; Cynosurus cristatus 1 in $5,+$ in 6 ; Poa angustifolia 1 in 5 and 6; Ranunculus flammula 1 in 5, + in 9; Succisa pratensis + in 6, 1 in 7; Festuca trichophylla s.l. 1 in 6,+ in 7; Trifolium pratense 1 in 5, + in 8; Danthonia decumbens + in 6 and 7; Cerastium vulgare 1 in 7, + in 8; Nardus stricta + in 7, 1 in 9; Equisetum palustre, Stellaria alsine and Trifolium repens 1, Glyceria declinata and Montia amporitana + in 5; Eleocharis quinqueflora in 1, Polygala vulgaris and Sparganium neglectum + in 7; Geum hispidum, Trifolium montanum and Veronica beccabunga +in 8; Juncus bulbosus 1 in 9. 
Localities: 1: Guadalajara, Checa, Los Manaderos, 30TXK0378, 2-8-2012, holotypus subass.; 2, 8: Teruel, Sierra del Tremedal, Garganta de los Avellanos, 30TXK1186, 1-8-2012; 3, 4: Teruel, Sierra del Tremedal, Ojos de Orihuela, 30TXK1488, 1-8-2012; 5, 6: Guadalajara, Orea, río Hoz Seca, 30TXK1083, 20-7-2010; 7: Guadalajara, Checa, Fuente de los Huecos, 30TXK1083, 21-7-2010; 9: Teruel, Sierra de Albarracín, Monte Pinar, near Fuente del Canto, 30TXK1584, 1-8-2012; 10: Teruel, Sierra del Tremedal, Tremedal de la Covatilla, 30TXK1285, 1-8-2012.

nez) are invalid names (ICBN, Art. 37.1), Caricetum carpetanae Rivas-Martínez 1964 becomes also an invalid name (ICPN, Art. 31) and the same applies to Caricetum ibericae Rivas-Martínez 1989 (ICPN, Art. 3o, 5). Other invalid proposal was the provisional (ICPN, art. 3b) association Carex echinata-Sphagnum inundatum Tüxen in TÜXEN \& OBERDORFER 1958 (pages: 167-168, tab. 52). Hence the first valid name and its authority are the indicated above.

\section{SiLICEOUS THYME-GRASSLANDS}

Fumano procumbentis-Thymetum izcoi $\mathbf{G}$. Navarro ass. nova hoc loco (Table 3)

Typus associatio: Characteristics: Thymus izcoi 3, Plantago holosteum 2, Pilosella castellana 2, Jasione sessiliflora 1. Companions: Potentilla cinerea 3, Festuca gracilior 2, Sedum amplexicaule 2, Minuartia hybrida 2, Molineriella laevis 2, Jasione montana 1, Fumana procumbens 1 , Helianthemum apenninum 1, Helianthemum incanum 1, Teucrium expassum 1, Saxifraga dichotoma 1, Herniaria cinerea 1 , Leontodon longirostris $1, P i$ losella officinarum 1, Asperula cynanchica 1,Calluna vulgaris + , Halimium viscosum + , Lavandula pedunculata,+ Cerastium gracile 1, Corynephorus canescens + , Eryngium campestre + , Tuberaria guttata + . Locality: Villaciervo (Soria), alt. 1140 m, 30TWM2023, area $20 \mathrm{~m}^{2}$ (NAVARRo, 1986).

(Hieracio castellani-Plantaginion radicatae Rivas-Martínez \& Cantó 1987, Jasiono sessiliflorae-Koelerietalia crassipedis Rivas-Martínez \& Cantó 1987, Festucetea indigestae Rivas Goday \& Rivas-Martínez 1971).

Supra(sub)mediterranean and lower orosubmediterranean communities dominated by dwarf chamaephytes and grass-like hemicryptophytes colonizing siliceous bedrock soils (slates, sandstones, quartzites). Their floristic combination is characterized by species of Festucetea indigestae s.l.: Thymus leptophyllus subsp. izcoi, Festuca rivas-martinezii, Plantago holosteum, Jasione sessiliflora, Pilosella castellana, Leucanthemopsis pallida subsp. virescens and Koeleria crassipes. In the scrub clearings, silicicolous terophytes of Tuberarietalia become frequent: Aira caryophyllea, Evax carpetana, Rumex acetosella subsp. angiocarpus, Scleranthus polycarpos and Trifolium striatum.

Thymus leptophyllus subsp. izcoi is an Oroiberian endemic but absent from the eastern Oroiberian mountains (Sierra de Gúdar and Javalambre). It characterizes these Oroiberian silicicolous dwarfchamaephytic communities and differentiates them from the related Carpetan-Leonese and Betic associations.

This communities are obviously related to the association proposed by NAVARRO (1986) in his thesis dissertation about the vegetation of the Sierras de Urbión, Neila and Cabrejas (northern Iberian System), although the thyme species was then identified as 'Thymus godayanus subsp. celtibericus'. Unfortunately, the association was never published neither compiled in the syntaxonomic checklists of vascular plant communities of the Iberian Peninsula (RIVAS-MARTínez \& al., 2001, $2002,2011)$. Our phytosociological data from the southwestern Oroiberian mountains confirm that this association has an important distribution area linked to the supramediterranean-suprasubmediterranean and lower orosubmediterranean belts of Oroiberian siliceous mountains, growing on sandstones, slates, quartzite bedrocks and also in Albian sandy outcrops. The synoptic table of NAVARRO (op. cit.) has been also included in Table 3 to show the floristic similarities among both Oroiberian territories through common species like Thymus leptophyllus subsp. izcoi, Plantago holosteum, Pilosella castellana, Koeleria crassipes and Jasione crispa subsp. sessiliflora. The northern Oroiberian communities were mostly sampled by Navarro at lower altitudes (1050-1200 m) 


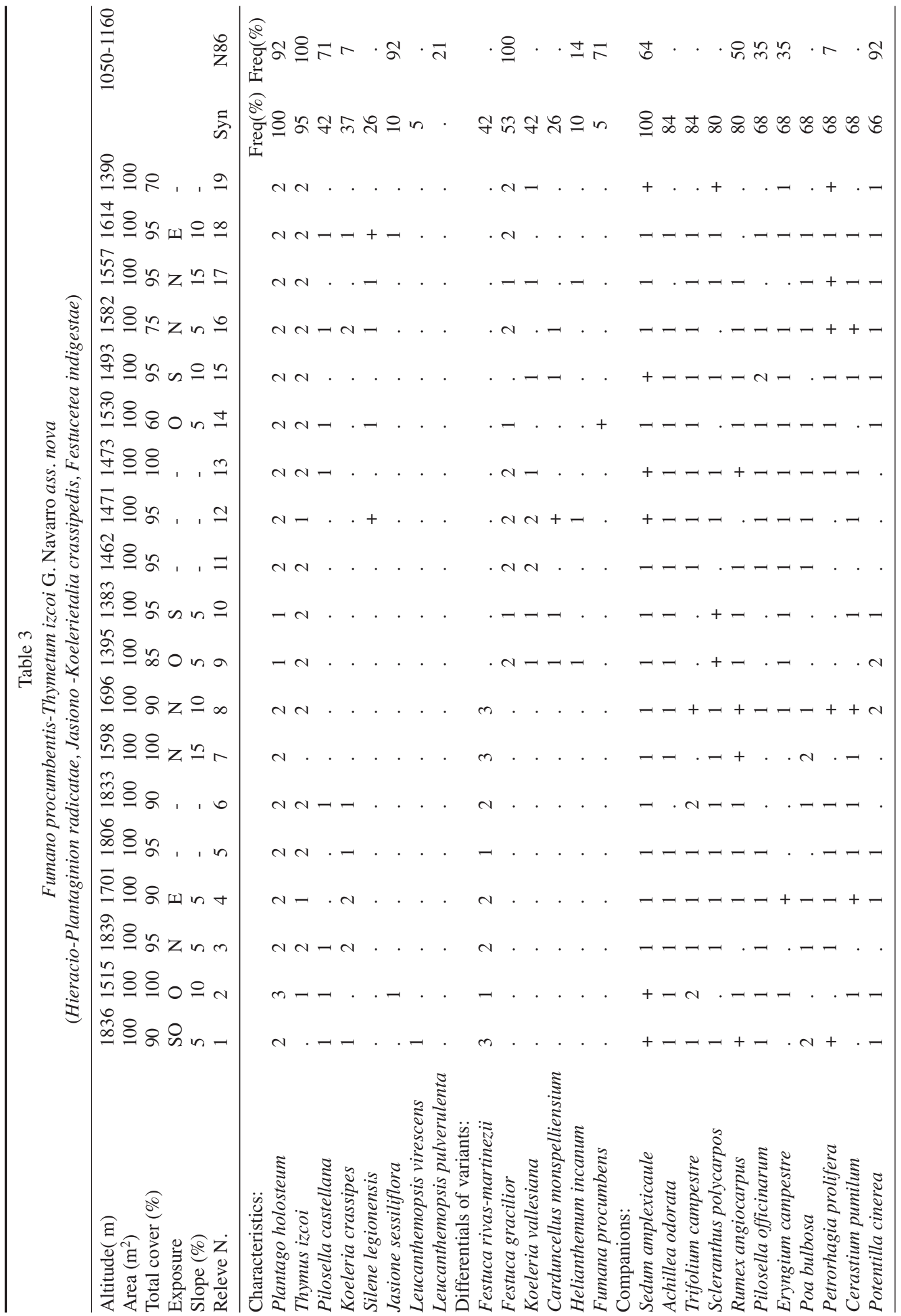




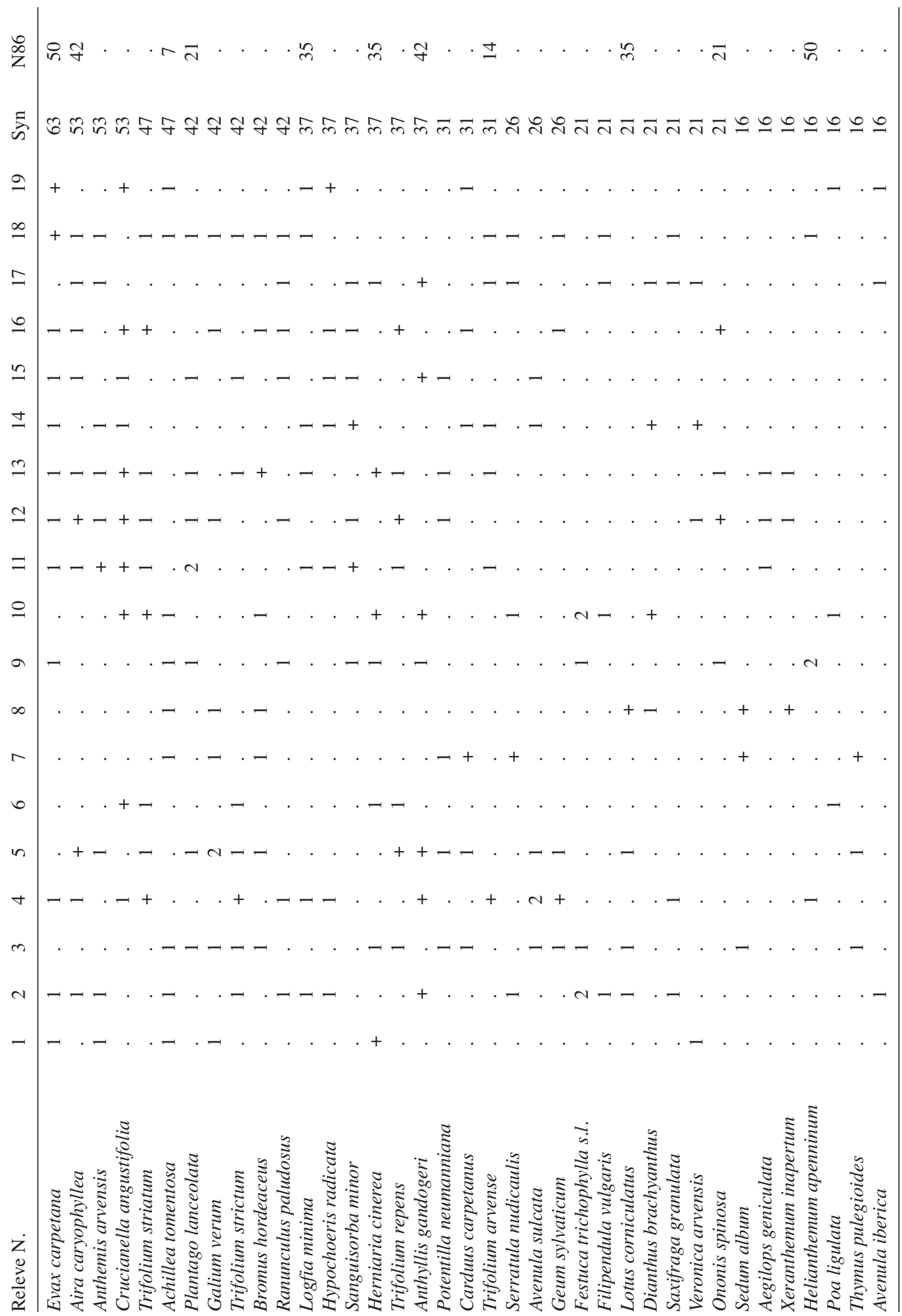




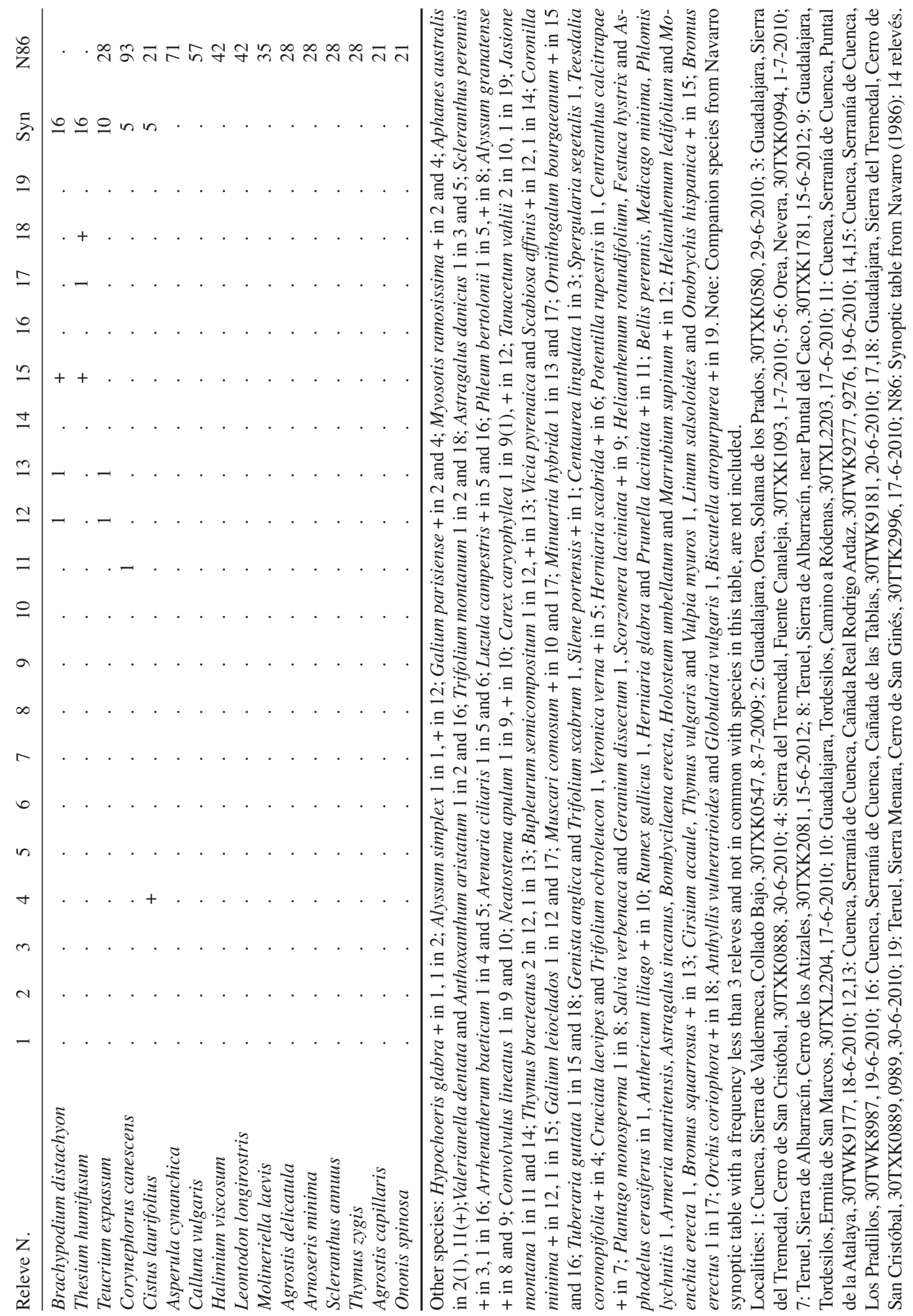


Table 4

Genisto anglicae-Nardetum strictae Rivas-Martínez \& Sánchez-Mata in Rivas-Martínez, Fernández-González \& Sánchez-Mata 1986

(Campanulo herminii-Nardion, Nardetalia, Nardetea)

\begin{tabular}{|c|c|c|c|c|c|c|c|c|c|c|c|c|c|}
\hline Altitude (m) & 1307 & 1320 & 1339 & 1355 & 1622 & 1775 & 1694 & 1606 & 1530 & 1510 & 1634 & 1652 & \\
\hline $\begin{array}{l}\text { Area }\left(\mathrm{m}^{2}\right) \\
\text { Exposure }\end{array}$ & $\begin{array}{l}100 \\
-\end{array}$ & $\begin{array}{l}100 \\
\mathrm{E}\end{array}$ & $\begin{array}{l}100 \\
-\end{array}$ & $\begin{array}{l}100 \\
-\end{array}$ & 100 & $\begin{array}{l}100 \\
-\end{array}$ & $\begin{array}{l}100 \\
S\end{array}$ & & $\begin{array}{l}100 \\
-\end{array}$ & $\begin{array}{l}100 \\
\mathrm{NO}\end{array}$ & & & \\
\hline Slope $\left({ }^{\circ}\right)$ & - & 5 & - & - & - & - & 10 & - & - & 5 & - & - & \\
\hline Releve N. & 1 & 2 & 3 & 4 & 5 & 6 & 7 & 8 & 9 & 10 & 11 & 12 & Syn \\
\hline Characteristics: & & & & & & & & & & & & & Freq. (\%) \\
\hline Nardus stricta & 3 & 2 & 3 & 2 & 3 & 5 & 2 & 3 & 3 & 4 & 3 & 3 & 100 \\
\hline Genista anglica & 2 & 3 & 2 & 1 & 2 & 1 & 2 & 3 & 3 & 2 & 2 & 3 & 100 \\
\hline Luzula campestris & 1 & . & . & . & 1 & + & . & 1 & + & 1 & 1 & 1 & 66 \\
\hline Danthonia decumbens & 1 & 2 & 1 & 2 & . & . & + & . & + & + & . & . & 58 \\
\hline Euphrasia hirtella & 1 & 1 & 1 & 1 & 1 & . & . & + & 1 & . & . & . & 58 \\
\hline Juncus squarrosus & . & 1 & . & . & 1 & . & 1 & 1 & 1 & . & 1 & + & 58 \\
\hline Potentilla erecta & . & . & . & . & . & 1 & . & . & 1 & 1 & + & + & 41 \\
\hline Carex leporina & . & . & . & . & 1 & 1 & . & 1 & . & . & 1 & + & 41 \\
\hline Polygala vulgaris & . & . & . & . & . & + & 1 & . & 1 & . & + & . & 33 \\
\hline Leontodon carpetanus & 1 & . & 1 & 1 & . & . & . & . & . & . & . & . & 25 \\
\hline Dianthus deltoides & . & . & . & . & 1 & . & . & . & . & . & . & 1 & 16 \\
\hline $\begin{array}{l}\text { Luzula multiflora } \\
\text { Companions: }\end{array}$ & . & . & . & . & . & . & 2 & . & . & . & . & . & 8 \\
\hline Carum verticillatum & 1 & 1 & 1 & 1 & 1 & 1 & 1 & 1 & 1 & 1 & + & + & 100 \\
\hline Ranunculus aleae & 1 & 1 & + & 1 & 1 & 1 & + & 1 & 1 & + & 1 & 1 & 100 \\
\hline Galium verum & 1 & 1 & 1 & 1 & 1 & 1 & . & 1 & 1 & 1 & 1 & 1 & 91 \\
\hline Deschampsia subtriflora & 1 & 1 & 2 & 1 & . & 1 & . & + & 1 & . & 1 & 1 & 75 \\
\hline Lotus corniculatus & 1 & 1 & 1 & 1 & 1 & 1 & 1 & 1 & . & . & + & . & 75 \\
\hline Festuca trichophylla s.l. & 2 & . & 2 & 1 & 1 & 1 & 1 & 2 & 1 & . & . & . & 66 \\
\hline Pilosella officinarum & 1 & 1 & 1 & . & 1 & 1 & . & 1 & 1 & 1 & . & . & 66 \\
\hline Plantago media & 1 & 1 & 1 & 2 & 1 & . & . & 1 & + & . & + & . & 66 \\
\hline Filipendula vulgaris & 1 & 1 & 1 & 1 & 1 & . & . & . & 1 & . & + & . & 58 \\
\hline Anthoxanthum odoratum & 2 & 1 & . & 1 & . & 1 & 2 & . & . & . & 2 & . & 50 \\
\hline Centaurea jacea & 1 & 1 & 2 & 1 & . & . & . & . & . & . & 1 & 2 & 50 \\
\hline Galium leioclados & . & . & . & . & 1 & 1 & . & 1 & 1 & 1 & 1 & . & 50 \\
\hline Avenula sulcata & . & . & . & . & . & 1 & 1 & 1 & . & 2 & 1 & 1 & 50 \\
\hline Holcus lanatus & 1 & 1 & . & . & . & . & 1 & 1 & . & 1 & 1 & . & 50 \\
\hline Trifolium pratense & . & 1 & 1 & . & 1 & 1 & 1 & . & . & . & . & + & 50 \\
\hline Orchis coriophora & + & + & 1 & . & + & . & + & . & + & . & . & . & 50 \\
\hline Cynosurus cristatus & . & 1 & 1 & 3 & . & . & 1 & . & . & . & 1 & . & 41 \\
\hline Stachys officinalis & 1 & 1 & . & . & 1 & . & . & . & + & . & + & . & 41 \\
\hline Carex panicea & 1 & . & . & 1 & . & + & 1 & . & . & . & + & . & 41 \\
\hline Hypochoeris radicata & 1 & 1 & . & . & . & . & 1 & . & . & . & + & + & 41 \\
\hline Cerastium vulgare & . & . & . & . & . & . & 1 & 1 & . & 1 & + & 1 & 41 \\
\hline Geum hispidum & . & . & . & . & . & . & 1 & 1 & . & 1 & + & 1 & 41 \\
\hline Briza media & . & . & . & 1 & . & 1 & 1 & . & 1 & . & + & . & 41 \\
\hline Trifolium dubium & . & . & 1 & 1 & 1 & . & . & 1 & . & . & + & . & 41 \\
\hline Aira caryophyllea & + & 1 & . & . & 1 & . & . & + & 1 & . & . & . & 41 \\
\hline Bellis perennis & . & . & . & . & 1 & 1 & + & 1 & . & . & + & . & 41 \\
\hline Saxifraga granulata & . & . & . & . & + & 1 & . & 1 & 1 & + & . & . & 41 \\
\hline Phleum bertolonii & . & . & + & . & 1 & . & 1 & . & + & . & + & . & 41 \\
\hline Prunella laciniata & 1 & 1 & 1 & . & . & . & . & + & . & . & . & . & 33 \\
\hline Poa angustifolia & . & . & . & . & . & . & 1 & . & . & 1 & 1 & . & 25 \\
\hline Agrostis castellana & . & . & . & . & 1 & . & 1 & . & ${ }^{\circ}$ & 1 & . & . & 25 \\
\hline Juncus effusus & . & . & . & . & . & . & 1 & . & . & . & 1 & 1 & 25 \\
\hline Trifolium montanum & 1 & 1 & . & . & . & . & . & . & 1 & . & . & . & 25 \\
\hline Rhinanthus minor & . & . & + & . & . & 1 & 1 & . & . & . & . & . & 25 \\
\hline Thymus pulegioides & . & . & . & . & 1 & . & . & . & + & 1 & . & . & 25 \\
\hline Myosotis arvensis & . & . & . & . & + & . & . & 1 & + & . & . & . & 25 \\
\hline
\end{tabular}


Other species: Carex caryophyllea 1 in 1 and 2; Trifolium campestre + in 2, 1 in 3; Festuca fenas 1 in 2 and 4; Juncus striatus + in 2, 1 in 4; Taraxacum vulgare 1 in 3 and 4; Euphorbia exigua + in 3 and 8; Potentilla reptans 1 in 4 and 10; Carex hirta + in 4 and 12; Cruciata laevipes 1 in 5 and 8; Ranunculus paludosus + in 5, 1 in 8; Viola canina + in 6, 1 in 12; Veronica arvensis 1 in 7 and 8; Plantago lanceolata 1 in 7, + in 11; Cerastium semidecandrum, Conopodium pyrenaeum and Juncus conglomeratus + in 2; Juncus bufonius and Radiola linoides 1 in 3; Gaudinia fragilis, Juncus inflexus and Trifolium repens 1, Mentha pulegium and Teucrium scordium + in 4; Anthemis arvensis and Rumex angiocarpus 1, Ornithogalum bourgaeanum + in 5; Bromus rigidus, Sanguisorba minor and Veronica officinalis + in 6; Hypericum undulatum and Trisetum flavescens 1, Dactylis glomerata and Linum catharticum + in 7; Trifolium strictum 1, Aphanes australis, Plantago holosteum and Poa bulbosa + in 8; Prunella vulgaris 1, Centaurea nevadensis + in 9; Achillea ptarmica, Festuca rivas-martinezii, Parnassia palustris, Seseli cantabricum, Succisa pratensis and Trifolium ochroleucon 1, Cirsium acaule + in 10; Bromus hordeaceus and Molinia caerulea 1, Carex flacca and Cruciata pedemontana + in 11 .

Localities: 1, 2: Cuenca, Serranía de Cuenca, Fuente del Cascajar, 30TWK8078, 7978, 24-6-2009; 3: Cuenca, Serranía de Cuenca, Fuente Morena, 30TWK8281, 24-6-2009; 4: Cuenca, Serranía de Cuenca, Pino Alto 30TWK8279, 246-2009; 5: Guadalajara, Sierra del Tremedal, Cerro de San Cristóbal, 30TXK0989, 30-6-2010; 6: Guadalajara, Sierra del Tremedal, Collado de los Santos, 30TXK0987, 30-6-2010; 7: Guadalajara, Sierra del Tremedal, Fuente Canaleja, 30TXK1093, 1-7-2010; 8: Guadalajara, Checa, P.N. Alto Tajo, Los Asperones, 30TXK0175, 2-7-2010; 9: Guadalajara, Checa, P.N. Alto Tajo, Fuente Canalón, 30TXK0089, 2-7-2010; 10: Teruel, Orea, Solana de los Prados, 30TXK0580, 20-7-2010; 11,12: Teruel, Sierra de Albarracín, Fuente Juan Ramón, 30TXK2081, 2082, 15-6-2012.

on soils developed on white sands which favor a higher frequence of Corynephorus canescens, $\mathrm{Ha}$ limium viscosum and Lavandula pedunculata. On the contrary, Koeleria crassipes occurs at altitudes above $1550 \mathrm{~m}$ denoting an altitudinal variant in the southwestern Oroiberian communities. Most likely, NAVARRo seems to have misinterpreted Festuca gracilior as $F$. aragonensis ( $F$. indigesta subsp. aragonensis), as we sampled fescue specimens in the area studied by him and they correspond to $F$. gracilior. Other floristic trend of variation concerns the proportion of calciphile species represented in these thyme-grasslands. When they colonize sandy outcrops adjacent to calcareous substrates, as it usually occurs in the foothills of calcareous highlands, the vicinity to dry basophilous grasslands favors the entry of several calciphile species like Festuca gracilior, Fumana procumbens, Koeleria vallesiana, Carduncellus monspelliensium and Helianthemum oelandicum subsp. incanum (Festuca gracilior variant: Table 3 , relevés 9-19). On the contrary, relevés 1-8 of Table 3 are poorer in calciphile species (Festuca rivas-martinezii variant).

\section{NARDUS SWARDS}

Genisto anglicae-Nardetum strictae RivasMartínez \& Sánchez-Mata in Rivas-Martínez, Fernández-González \& Sánchez-Mata 1986 (Table 4)
(Campanulo herminii-Nardion Rivas-Martínez, Fernández-González \& Sánchez-Mata 1986, Nardetalia Oberdorfer ex Preising 1949, Nardetea Rivas Goday in Rivas Goday \& Rivas-Martínez 1963)

This association includes supratemperate (submediterranean) Nardus swards with Genista anglica that grow on siliceous deep soils with permanent hydromorphic processes. They were firstly described in the western Central System (RivAS-MARTíneZ \& al., 1986; SÁNCHEZ-MATA, 1989; SARDINERO, 2005) and recognized also in its eastern part, Sierra de Ayllón (DE LA CRUZ, 1994; RodríGUEZ-Rojo, 2003). Genista anglica is absent from Sierra de Guadarrama, where the suprasubmediterranean Nardus swards have been referred to the vicariant association Festuco rothmaleri-Juncetum squarrosi Rivas-Martínez, Fernández-González, Sánchez-Mata \& Pizarro 1990. The floristic combination proper of Genisto-Nardetum again occurs in the southwestern Iberian System, hence its biogeographic distribution must be enlarged to the Oroiberian sectors. The abundance of siliceous bedrocks in Sierra de Albarracín favors suitable biotopes for these grasslands, which still may grow in some siliceous outcrops at the valley bottoms or in the confluence of trickles of water in Alto Tajo and Serranía de Cuenca.

This association is framed into Campanulo herminii-Nardion, although is relatively poor in 
Table 5

Deschampsio hispanicae-Juncetum effusi Rivas-Martínez ex R. García in Llamas 1984 (1-8) Hyperico undulati-Juncetum acutiflori Teles 1970 (9-12)

(Juncion acutiflori, Molinietalia caeruleae, Molinio-Arrhenatheretea)

\begin{tabular}{|c|c|c|c|c|c|c|c|c|c|c|c|c|c|}
\hline $\begin{array}{l}\text { Altitude }(\mathrm{m}) \\
\text { Area }\left(\mathrm{m}^{2}\right) \\
\text { Releve N. }\end{array}$ & $\begin{array}{l}1585 \\
100 \\
1\end{array}$ & $\begin{array}{l}1600 \\
100 \\
2\end{array}$ & $\begin{array}{l}1700 \\
100 \\
3\end{array}$ & $\begin{array}{l}1686 \\
100 \\
4\end{array}$ & $\begin{array}{l}1510 \\
100 \\
5\end{array}$ & $\begin{array}{l}1510 \\
100 \\
6\end{array}$ & $\begin{array}{l}1532 \\
50 \\
7\end{array}$ & $\begin{array}{l}1740 \\
100 \\
8\end{array}$ & $\begin{array}{l}1450 \\
50 \\
9\end{array}$ & $\begin{array}{l}1670 \\
25 \\
10\end{array}$ & $\begin{array}{l}1477 \\
100 \\
11\end{array}$ & $\begin{array}{l}1480 \\
100 \\
12\end{array}$ & Syn \\
\hline Characteristics & & & & & & & & & & & & & Freq. (\%) \\
\hline Juncus effusus & 3 & 2 & 4 & 3 & 3 & 3 & 3 & 3 & 1 & 2 & 2 & . & 92 \\
\hline Juncus acutiflorus & . & . & . & . & 1 & 1 & 1 & 1 & 3 & 4 & 3 & 3 & 67 \\
\hline Hypericum undulatum & 2 & 1 & 1 & 1 & 2 & . & 2 & 1 & 2 & 1 & 1 & 2 & 92 \\
\hline Carum verticillatum & 1 & 1 & 1 & 1 & . & 1 & 2 & 1 & 2 & 1 & 1 & + & 92 \\
\hline Galium palustre & 1 & 1 & 1 & . & 1 & 2 & 2 & 1 & 2 & 1 & 1 & 1 & 92 \\
\hline Carex panicea & . & . & . & . & + & . & . & . & . & + & 1 & + & 33 \\
\hline Lychnis flos-cuculi & 1 & 1 & . & . & 1 & . & . & . & . & + & 2 & 1 & 58 \\
\hline Ranunculus flammula & . & . & . & . & 1 & 1 & . & 1 & . & . & 1 & . & 33 \\
\hline Lotus pedunculatus & . & . & . & 1 & . & 1 & . & . & . & . & + & . & 25 \\
\hline Companions: & & & & & & & & & & & & & \\
\hline Holcus lanatus & 1 & 2 & 1 & 1 & 1 & 2 & 1 & 2 & 2 & 1 & 1 & 1 & 100 \\
\hline Anthoxanthum odoratum & 1 & 1 & 2 & 1 & 1 & 1 & 2 & 1 & . & 1 & 1 & 1 & 92 \\
\hline Cynosurus cristatus & + & 1 & 1 & 1 & 1 & 1 & 1 & + & 2 & . & 1 & + & 92 \\
\hline Poa trivialis & 1 & 1 & 1 & 1 & 1 & . & 2 & 1 & 2 & + & 2 & 1 & 92 \\
\hline Briza media & + & . & . & 1 & 1 & 1 & 1 & . & 1 & + & 1 & . & 67 \\
\hline Carex leporina & 2 & 2 & 1 & 2 & + & 1 & . & 1 & . & + & . & . & 67 \\
\hline Mentha longifolia & 2 & 2 & 1 & 1 & . & . & . & 1 & . & 1 & 1 & + & 67 \\
\hline Trifolium pratense & + & . & 1 & 1 & 1 & 1 & 1 & + & . & . & 1 & . & 67 \\
\hline Carex echinata & . & . & . & . & 1 & 1 & 1 & 1 & 1 & 1 & 1 & . & 58 \\
\hline Prunella vulgaris & . & . & . & . & 1 & 1 & 2 & + & 2 & 1 & . & 1 & 58 \\
\hline Ranunculus repens & . & . & . & . & 1 & 1 & 1 & 1 & 1 & 1 & . & 1 & 58 \\
\hline Cerastium vulgare & 1 & . & . & . & + & . & . & + & . & 1 & + & + & 50 \\
\hline Luzula multiflora & . & 1 & . & . & 1 & 1 & . & 1 & . & + & 1 & . & 50 \\
\hline Potentilla erecta & . & . & . & . & 1 & 1 & 1 & 1 & . & 1 & + & . & 50 \\
\hline Ranunculus despectus & 1 & 1 & 1 & 1 & 1 & . & . & . & . & . & 1 & . & 50 \\
\hline Epilobium palustre & . & . & . & . & . & . & + & + & 1 & + & . & 1 & 42 \\
\hline Geum hispidum & . & + & 1 & 1 & + & . & . & + & . & . & . & . & 42 \\
\hline Lathyrus pratensis & + & 1 & . & . & . & . & + & . & . & . & + & 1 & 42 \\
\hline Leontodon hispidus & + & + & . & . & + & + & . & . & . & . & . & 1 & 42 \\
\hline Trifolium repens & . & . & . & 1 & 1 & 1 & 1 & . & 2 & . & . & . & 42 \\
\hline Carex nigra & . & . & . & . & . & . & 1 & 1 & . & 1 & 1 & . & 33 \\
\hline Dactylorhiza elata & + & . & + & + & . & . & . & + & . & . & . & . & 33 \\
\hline Glyceria declinata & . & . & . & . & 1 & + & . & 1 & 1 & . & . & . & 33 \\
\hline Phleum bertolonii & . & 1 & 1 & 1 & . & . & . & . & . & + & . & . & 33 \\
\hline Poa angustifolia & 1 & 2 & . & 1 & . & 1 & . & . & . & . & . & . & 33 \\
\hline Veronica scutellata & . & . & . & . & . & . & 1 & + & 1 & . & 1 & . & 33 \\
\hline Genista anglica & . & . & . & . & . & . & . & + & . & . & + & + & 25 \\
\hline Luzula campestris & + & . & 1 & 1 & . & . & . & . & . & . & . & . & 25 \\
\hline Myosotis caespitosa & . & . & . & . & 1 & 1 & . & . & . & . & + & . & 25 \\
\hline Nardus stricta & . & . & . & . & . & 1 & . & 1 & . & 1 & . & . & 25 \\
\hline Stellaria graminea & . & 1 & 1 & . & . & . & . & . & . & . & + & . & 25 \\
\hline
\end{tabular}

Other species: Myosotis arvensis 1 in 1 and 2; Carex pairae 1 in 2 and 4; Orchis coriophora + in 3 and 4; Vicia angustifolia + in 3, 1 in 4; Agrostis stolonifera 1 in 6,+ in 8; Bellis perennis 1 in 4 and 5; Epilobium obscurum 1 in 5, + in 6; Cardamine castellana 1 in 7 and 9; Molinia caerulea 1 in 7 and 12; Carex flacca + in 10, 1 in 11; Dactylorhiza incarnata + in 11 and 12; Vicia sativa + in 2; Equisetum palustre, Juncus bulbosus, Linum catharticum, Scirpus setaceus and Veronica beccabunga 1 in 5; Leontodon carpetanus 1 in 6; Sphagnum sp. 1 in 8; Carex rostrata 2, Deschampsia subtriflora and Juncus conglomeratus 1 in 11. 
Localities: 1-2: Guadalajara, Orea, Cañada Real de Merinas, 30TXK0892, 1-7-2010; 3: Guadalajara, Orea, Fuente Canaleja, 30TXK0993, 1-7-2010; 4: Guadalajara, Orea, Barranco de la Nevera, 30TXK0894, 1-7-2010; 5-6: Guadalajara, Orea, Fuente Jícara, 30TXK0580, 20-7-2010; 7, 9: Cuenca, Sierra de Valdemeca, Hoya de la Soldada, 30TXK0353, 29-7-2009; 8: Teruel, Sierra del Tremedal, Arroyo Gargantavellanos, 30TXK1186, 1-8-2012; 10: Teruel, Sierra del Tremedal, Tremedal del Campillejo, 30TXK1286, 1-8-2012; 11-12: Teruel, Sierra del Tremedal, Ojos de Orihuela, 30TXK1488, 1-8-2012.

character species of the alliance and order, which are more frequent and abundant at higher altitudes (cryoro- and orotemperate (submediterranean) belts). The main floristic difference between Carpetan and Maestracensean communities of Genisto anglicae-Nardetum strictae deals with some vicariant species of Festuca aggr. rubra: F. rothmaleri is a common species in the former, while F. trichophylla s.l. seems to be the correspondent species in the Maestracensean Nardus grasslands.

\section{RUSH MEADOWS}

Deschampsio hispanicae-Juncetum effusi Rivas-Martínez ex R. García in Llamas 1984 (Table 5, rel. 1-8) and Hyperico undulatiJuncetum acutiflori Teles 1970 (Table 5, rel. 9-12)

(Juncion acutiflori Br.-Bl. in Br.-Bl. \& Tüxen 1952, Molinietalia caeruleae Koch 1926, Molinio-Arrhenatheretea Tüxen 1937)

Wet silicicolous meadows dominated by Juncus effusus or J. acutiflorus, with a Mediterranean Western Atlantic distribution, and an optimum in the supramediterranean and suprasubmediterranean climates. They grow on soils remaining moist during almost all the year, with a sand-silty texture and a pseudogley soil horizon. Both associations have their main distribution in the Carpetan-Leonese and Oroiberian territories. In the southwestern Iberian System, these rush communities are mainly found in the siliceous mountains of Sierra de Albarracín and Sierra de Valdemeca. The main differences are related to floristic impoverishment, because some floristic elements common in the rush meadows from Carpetan and northwestern Oroberian mountains, like Galium rivulare and Carex binervis, seem to be lacking in the southwestern Oroiberian communities.

Rush meadows dominated by Juncus effusus correspond to Deschampsio-Juncetum effusi, while the most hygrophilous meadows are dominated by Juncus acutiflorus, often accompanied by some sedges (Carex echinata, C. panicea), and correspond to Hyperico-Juncetum acutiflori.

\section{ACKNOWLEDGEMENTS}

This research was carried out with the financial aid of the University of Castilla-La Mancha Research Program during 2009-2010 (TC20091114), and the Global Change, Earth Sciences and Biodiversity Program of the Spanish Ministry of Education and Science (CGL2009-13317-C03-03, project SIVIM) 


\section{FLORISTIC APPENDIX}

We list here by alphabetical order the abbreviated referred taxa in the previous text and phytosociological tables:

Anthyllys gandogeri: Anthyllis vulneraria subsp. gandogeri

Anthyllis vulnerarioides: Anthyllis vulneraria subsp. vulnerarioides

Arenaria ciliaris: Arenaria obtusiflora subsp. ciliaris

Armeria matritensis: Armeria alliacea subsp. matritensis

Arrhenatherum baeticum: Arrhenatherum elatius subsp. baeticum

Avenula iberica: Avenula pratensis subsp. iberica

Carex pairae: Carex muricata subsp. pairae

Centaurea lingulata: Centaurea triumfetti subsp. lingulata

Cerastium vulgare: Cerastium fontanum subsp. vulgare

Deschampsia subtriflora: Deschampsia caespitosa subsp. subtriflora

Dianthus brachyanthus: Dianthus pungens subsp. brachyanthus

Galium leioclados: Galium estebanii subsp. leioclados

Halimium viscosum: Halimium umbellatum subsp. viscosum

Helianthemum incanum: Helianthemum oelandicum subsp. incanum

Jasione sessiliflora: Jasione crispa subsp. sessiliflora

Leucanthemopsis virescens: Leucanthemopsis pallida subsp. virescens

Montia amporitana: Montia fontana subsp. amporitana

Myosotis caespitosa: Myosotis laxa subsp. caespitosa

Onobrychis hispanica: Onobrychis argentea subsp. hispanica

Poa angustifolia: Poa pratensis subsp. angustifolia

Rumex despectus: Ranunculus acris subsp. despectus

Ranunculus aleae: Ranunculus bulbosus subsp. aleae

Rumex angiocarpus: Rumex acetosella subsp. angiocarpus

Rumex gallicus: Rumex bucephalophorus subsp. gallicus

Scabiosa affinis: Scabiosa columbaria subsp. affinis

Sparganium neglectum: Sparganium erectum subsp. neglectum

Thymus izcoi: Thymus leptophyllus subsp. izcoi

\section{REFERENCES}

Barrera, I. - 1985 - Contribución al estudio de la flora y de la vegetación de la Sierra de Albarracín - Mem. Doc. (inéd.). F. Biología. Univ. Complutense, Madrid. 499 pp.

Del Egido Mazuela, F. \& Puente García, E. -2011 - Sobre los nombres correctos de dos asociaciones homónimas: Epipactido palustris-Eriophoretum latifolii - Lazaroa 32: 181-182.

De la Cruz Rot, M. - 1994- El paisaje vegetal de la Cuenca del río Henares (Guadalajara) - Mem. Doc. (inéd.). F. Ciencias. Univ. Alcalá de Henares, Madrid. 473 pp.

Fernández-González, F. -1988- Estudio florístico y fitosociológico del Valle del Paular (Madrid) - Mem. Doc. (inéd.). F. Biología. Univ. Complutense, Madrid. 759 pp.

García Cardó, O. \& Sánchez Melgar, I. -2005- Aportaciones a la flora de la provincia de Cuenca - Flora Montib. 29: 105-119.

Gómez-Serrano, M.A. \& Mayoral, O. -2003- Aportaciones a la flora de Cuenca, I - Flora Montib. 24: 33-42.

Gómez-Serrano, M.A. \& Laguna Lumbreras, E. - 2011Potentilla fruticosa L. en el Sistema Ibérico - Flora Montib. 49: 15-23.
Gutiérrez Elorza, M. \& J.L. Peña Monné - 1994- Cordillera Ibérica - In: Gutiérrez Elorza, M. (coor.). Geomorfología de España. Pp. 251-286. Ed. Rueda, Madrid.

Jiménez-Alfaro, B., Fernández-Pascual; E., Díaz González, T.E., Pérez-Hasse, A. \& Ninot, J.M. - 2012 - Diversity of rich fen vegetation and related plant specialists in mountain refugia of the Iberian Peninsula - Folia Geobot. 47(4):403-419.

Loidi, J., Biurrun, I. \& Herrera, M. —1997- La vegetación del centro-septentrional de España - Itinera Geobot. 9: 161-618.

López González, G. -1976- Contribución al conocimiento fitosociológico de la Serranía de Cuenca, I An. Inst. Bot. Cavanilles 33: 5-87.

López González, G. - 1978- Contribución al conocimiento fitosociológico de la Serranía de Cuenca, II An. Inst. Bot. Cavanilles 34(2): 597-702.

Mateo, G., Hernández, M.L., Torres, S. \& Vila,A. - 1995Nuevos datos sobre la flora de la provincia de Cuenca, I - Flora Montib. 1: 33-37. 
Mateo, G., Mayoral, O. \& Gómez-Serrano, M.A. -2001 Nuevos Datos sobre la flora de la provincia de Cuenca, XVI - Flora Montib. 19: 45-52.

Munín, E. \& Fuertes, E. - 2001 - Revisión taxonómica del género Sphagnum L. Sección Cuspidata (Musci, Sphagnaceae) en la Península Ibérica - Lazaroa 22: 21-50.

Navarro, G. - 1986- Vegetación y flora de las Sierra de Urbión, Neila y Cabrejas. Mem. Doc. (inéd.). F. Biología. Univ. Complutense, Madrid.

Navarro, G. -1987- Datos sobre la vegetación acuática de las lagunas glaciares de Urbión y Neila (Soria-Burgos) - Lazaroa 7: 487-495.

Pitarch, R. - 2002 - Estudio de la Flora y Vegetación de las Sierras Orientales del Sistema Ibérico: La Palomita, Las Dehesas, El Rayo y Mayabona (Teruel) - Consejo de Protección de la Naturaleza de Aragón. 537 pp. Zaragoza.

Rivas-Goday, S. \& Borja, J. - 1961 - Estudio de la vegetación y flórula del macizo de Gúdar y Jabalambre An. Inst. Bot. Cavanilles 19: 1-550.

Rivas-Martínez, S. - 1964- Estudio de la vegetación y flora de las sierras de Guadarrama y Gredos - An. Inst. Bot. Cavanilles 21(1): 1-325.

Rivas-Martínez, S., Fernández-González, F. \& SánchezMata, D. -1986- Datos sobre la vegetación del Sistema Central y Sierra Nevada - Opus. Bot. Pharm. Complut. 2: 3-136.

Rivas-Martínez, S., Fernández González, F., Loidi, J., Lousa, M. \& Penas, A. - 2001 - Syntaxonomical checklist of vascular plant communities of Spain and Portu- gal to association level - Itinera Geobot. 14: 5-341.

Rivas-Martínez, S., Díaz, T.E., Fernández-González, F., Izco, J., Loidi, J., Lousã, M. \& Penas, A. - 2002 - Vascular plant communities of Spain and Portugal. Addenda to the syntaxonomical checklist of 2001 - Itinera Geobot. 15(1/2): 5-922.

Rivas-Martínez, S. -2007- Mapa de series, geoseries y permaseries de vegetación de España (Mapa de vegetación potencial de España). Parte I - Itinera Geobot. 17: 5-436.

Rivas-Martínez, S. - 2011 - Mapa de series, geoseries y geopermaseries de vegetación de España [Memoria del Mapa de Vegetación Potencial de España] Parte 2 - Itinera Geobot. 18(2): 5-424.

Rodríguez-Rojo, M.P. - 2003- Modelización y patrones de diversidad de las fitocenosis orófilas de interés pascícola del Sistema Central ibérico - Mem. Doc. (inéd.). F. Farmacia. Univ. Complutense, Madrid. 228 pp.

Sánchez-Mata, D. - 1989- Flora y vegetación del Macizo Oriental de la Sierra de Gredos (Ávila) - Publ. Inst. Gran Duque de Alba n. 25. 440 pp. Ávila.

Sardinero, S. -2004- Estudio de la flora y vegetación del Macizo Occidental de la Sierra de Gredos (Sistema Central, España) - Guineana 10: 1-474.

Tüxen, R. \& Oberdorfer, E. - 1958 - Eurosibirischen Phanerogamengesellschaften Spaniens. - Veröff. Geobot. Inst. Rübel (Zürich) 32: 1-328.

Weber, H.E., Moravec, J. \& Theurillat, J.-P. -2000 - International Code of Phytosociological Nomenclature J. Veg. Sci. 11(5): 739-768.

Recibido: 5 septiembre 2012

Aceptado: 11 octubre 2012 